\title{
Strategi Pengembangan Usahatani Bawang Putih dalam Upaya Peningkatan Pendapatan Petani di Kecamatan Miomaffo Barat
}

\author{
Waridjo ${ }^{\mathrm{a}}$, Yosefina M Fallo \\ ${ }^{a}$ Fakultas Pertanian, Universitas Timor, Kefamenanu, TTU - NTT, 85613, Indonesia. \\ ${ }^{b}$ Fakultas Pertanian, Universitas Timor, Kefamenanu, TTU - NTT, 85613, Indonesia.
}

\section{Article Info}

\section{Article history:}

Received 12 Januari 2015

Received in revised form 15 Februarii 2015

Accepted 26 Februari 2015

\section{Keywords:}

Porpusive sampling

Responden

Usahatani

\section{Abstrak}

Penelitian ini bertujuan untuk mengetahui strategi pengembangan usahatani bawang putih sebagai upaya peningkatan pendapatan petan di Kecamatan Miomaffo Barat KabupatenTimor Tengah Utara. Penentuan desa sampel dilakukan secara sengaja (porpusive sampling) yaitu Desa Fatuneno (luas lahan usaha 15 Ha dengan produksi sebanyak 48 Ton) dan Desa Noepesu (luas lahan usaha $10 \mathrm{Ha}$ dengan produksi 32 Ton). Responden diambil secara acak $10 \%$ dari setiap desa. Desa Fatuneno sebanyak 46 KK dari 460 KK dan Desa Noepesu 42 dari $423 \mathrm{KK}$. Total responden yang diambil yaitu 88 KK. Hasil penelitian menunjukan bahwa Sistem usahatani bawang putih di Kecamatan Miomaffo Barat belum dikembangkan secara intensif karena petani belum menerapkan sistem panca usahatani, diantaranya bibit yang dipakai adalah bibit lokal yang sudah dipakai oleh petani secara turun-temurun, tidak menggunakan pupuk baik pupuk organik maupun angornik, sehingga produksi yang dihasilkan juga belum optimal. Pendapatan yang diperoleh oleh petani dalam sekali musim tanam dengan luas garapan rata-rata 15 are sebesar Rp 2.472.898,00. Hasil analisis SWOT diperoleh koordinat (-0.08; 0.03 ) yang mana koordinat ini pada kuadran III. Posisi ini menandakan sebuah kegiatan usaha yang lemah namun sangat berpeluang. Rekomendasi strategi yang diberikan adalah Ubah Strategi, artinya disarankan untuk mengubah strategi sebelumnya. Sebab, strategi yang lama dikhawatirkan sulit untuk dapat menangkap peluang yang ada sekaligus memperbaiki usahatani yang tepat. (O)2016 dipubikasikan oleh Agrimor.

\section{Pendahuluan}

Negara Indonesia adalah negara agraris, dimana sebagian besar penduduknya mengandalkan sektor pertanian. Dari kondisi kepemilikan lahan yang sempit ditambah dengan sistem pertanian yang masih mengandalkan input produksi tinggi menyebabkan petani berada dalam lingkaran kemiskinan yang tidak putus-putusnya. Petani dengan pendapatan rendah tidak akan mampu menabung, meningkatkan pendidikan dan keterampilan, apalagi meningkatkan investasinya guna meningkatkan produksi. Dalam keterbatasan yang dilematis tersebut diperlukan jalan keluar yang bijaksana dengan membangun paradigma baru, yaitu sistem pertanian yang berwawasan ekologis, ekonomis dan berkesinambungan, ini sering juga disebut sustainable mix farming atau mix farming.

Pembangunan Pertanian di Nusa Tenggara Timur (NTT) memiliki peran strategis, karena bertujuan untuk meningkatkan hasil dan mutu produksi, mensejahterakan petani sehingga dapat memperluas kesempatan kerja dan kesempatan berusaha, melakukan pengembangan agribisnis dalam mendorong peningkatan pendapatan, dan mengoptimalisasi pemanfaatan sumberdaya alam agar tetap memperhatikan kelestarian lingkungan. Untuk mencapai tujuan ini diharapkan bisa menunjang pengembangan usaha pertanian di wilayah ini.

Salah satu usaha pertanian yang memiliki prospek pengembangan yan baik dan sudah dikembangkan di provinsi NTT yakni usaha pertanian dari sub sektor hortikulutura. Sub sektor ini juga terdiri dari beberapa komoditi yang berpeluang untuk dikembangkan di provinsi ini yakni komoditi bawang putih. Bawang putih merupakan tanaman hortikultura yang banyak dibutuhkan terutama dalam peranannya sebagai penambah citarasa makanan dan sebagai bumbu masak berbagai macam makanan, selain itu bawang putih juga sering digunakan sebagai obat-obatan untuk penyakit tertentu seperti tekanan darah tinggi, sakit kepala dan menurunkan kadar kolesterol. Dengan melihat manfaat dari bawang putih maka tidaklah heran jika komoditi ini terus dikembangkan, hal ini tersirat dari produksi bawang putih di provinsi NTT yang terus meningkat 4 tahun terakhir (BPS Prop. NTT, 2010).

Salah satu Kabupaten di NTT yang terus menggalakkan usahatani bawang putih yakni Kabupaten Timor Tengah Utara (TTU), dimana Pemerintah Kabupaten TTU mengupayakan daerah-daerah yang berpontensi untuk pengembangan bawang putih. Salah satu daerah yang berpotensi yakn Kecamatan Miomaffo Barat, hal ini disebabkan karena bawang putih cocok untuk tumbuh dan berkembang pada daerah dingin dengan ketinggian 700 $1100 \mathrm{~m} \mathrm{dpl}$ (di atas permukaan laut) dengan suhu rata-rata $20{ }^{\circ} \mathrm{C}-25{ }^{\circ} \mathrm{C}$ dan memiliki curah hujan rata-rata $1200-2400 \mathrm{~mm}$ per tahun serta menghendak tekstur tanah yang gembur dan subur.

Produksi bawang putih di Kecamatan ini selama 5 tahun terakhir terus mengalami penurunan, faktor penyebab utama antara lain keadaan iklim khususnya curah hujan yang tidak menentu mengakibatkan berpengaruh terhadap luasan areal tanam, luas panen maupun produksi secara keseluruhan, sedangkan pada musim tanam 2011 luas tanam 25 ha, luas panen 25 ha dengan total produksi bawang putih sebesar 80 ton (BPS Kab. TTU, 2011). Namun pada kenyataannya produksi bawang putih belum mampu memenuh permintaan bawang putih masyarakat di kabupaten ini. Hal ini ditandai dari masuknya bawang putih import dari Kabupaten Sabu dan Kabupaten Rote (survey awal). Untuk menjamin kesinambungan produksi bawang putih maka harus didukung oleh faktor seperti, ketersediaan sarana produksi pertanian, kegiatan usahatani bawang putih yang intensif yang juga meliputi kegiatan pengolahan dan distribusi, maupun hasil olahannya. Selain itu petani perlu mengevaluasi arus pendapatan tunai dari petaninya serta kemampuan mereka melihat peluang dan tantangan dari usaha tersebut. Menurut Samuelson dan
Nordhaus (2002) pendapatan merupakan jumlah seluruh uang yang diterima oleh seseorang atau rumah tangga selama jangka waktu tertentu.

Kenyataan di lapangan menunjukkan bahwa terdapat beberapa kendala yang di hadapi petani dalam pengusahaan bawang putih diantaranya kondis curah hujan yang tidak menentu, modal petani kecil dan harga bawang putih yang tidak stabil, sedangakan harga input yang terus meningkat, hal ini menyebabkan rendahnya petani yang mengusahakannya.

Untuk meningkatkan pendapatan petani maka perlu dilakukannya pengembangan usahatani bawang putih yang komersial dengan memperhatikan starategi-strategi pengembangan mulai dari proses pembudidayaan hingga proses pemasaran guna meningkatkan pendapatan petani. Dalam penentuan strategi tentunya petani dituntut untuk memperhatikan faktor external dan internal yang terkait. Tujuan penelitian adalah 1) Mengetahui gambaran usahatani; 2) Mengetahui pendapatan yang diperoleh dari usahatani, dan; 3 Mengetahui startegi pengembangan usahatani bawang putih di Kecamatan Miomaffo Barat Kabupaten TTU

\section{Metode}

Pengambilan sampel dilakukan secara bertahap diawali penentuan desa sampel dilakukan secara sengaja (porpusive sampling) yaitu Desa Fatuneno dan Desa Noepesu dengan pertimbangan desa tersebut mempunyai areal usaha yang luas dengan luas lahan pada Desa Fatuneno 15 ha dengan produksi sebanyak 48 ton sedangkan luas lahan Desa Noepesu 10 ha dengan produksi 32 ton. Penentuan responden dilakukan secara acak sederhana yaitu dengan mengambi $10 \%$ dari setiap desa dimana untuk Desa Fatuneno yang menjadi responden adalah $10 \%$ dari 460 kepala keluarga (KK) yaitu 46 KK, dan Desa Noepesu $10 \%$ dari $423 \mathrm{KK}$ yaitu 2142 . Total responden yang diambil yaitu $88 \mathrm{KK}$

Penelitian menggunakan metode survei. Data yang dikumpulkan terdiri atas dua macam yaitu data primer dan data sekunder. Data primer berasal dari petani contoh diperoleh melalui observasi dan wawancara berdasarkan daftar pertanyaan yang telah disiapkan. Sedangkan data skunder diperoleh dari kepustakaan yang berkaitan dengan penelitian ini, serta lembaga atau instans yang berhubungan dengan penelitian. Data primer meliputi identitas responden (umur, jenis kelamin, pekerjaan, jumlah anggota keluarga) dari usahatan bawang merah; profil usaha; jumlah kepemilikan; faktor produksi yang dimiliki; biaya produksi; serta penerimaan. Sedangkan data sekunder meliputi kondisi umum daerah penelitian (iklim dan faktor-faktornya, topografi, kondis tanah) dan kebijakan pemerintah yang berhubungan dengan pengembangan usahatani bawang putih tersebut. Data primer dan sekunder diperlukan untuk menjawab permasalahan serta untuk mencapai tujuan penelitian ini.

Pengamatan dan konsep pengukuran meliputi 1) Identitas responden yang meliputi nama, umur, jenis kelamin, pekerjaan, pendidikan formal dan nonformal. Luas tanam yaitu luas lahan yang ditanami bawang putih (ha) pada tahun 2011; 2) Profil usahatani bawang putih adalah gambaran pelaksanaan usahatani bawang putih meliputi ketersediaan subsistem sarana produks pertanian, subsistem produksi dan subsistem pengolahan, penyimpanan/ penampungan dan distribusi atau pemasaran bawang putih, hasil olahan. Fakto lingkungan usahatani bawang putih adalah semua faktor luar (eksternal), seperti iklim, edafik, biotik, teknologi, ekonomi, financial, sosial budaya dan kebijakan Pemerintah yang berkaitan langsung dengan usahatani bawang putih. Peluang pengembangan usahatani bawang putih adalah semua variabel yang memberikan kemungkinan untuk meningkatkan skala usahatani bawang putih Kendala pengembangan usahatani bawang putih adalah semua faktor baik teknik produksi, lingkungan, financial dan pemasaran yang menyebabkan usahatani bawang putih tidak bisa dilaksanakan atau ditingkatkan skala usahanya; 3) Produksi yaitu jumlah produk tanaman bawang putih yang 
diperoleh petani dalam satu tahun $(\mathrm{kg})$ pada Tahun 2011; 4) Biaya produksi adalah biaya yang dikeluarkan dalam usahatani bawang putih meliputi : Biaya benih (Rp/kg), Pupuk (Rp/kg), Biaya Pestisida (Rp/Liter), Biaya tenaga kerja dalam penelitian ini diukur dalam harian $(\mathrm{Rp})$; 5) Harga bawang putih yaitu harga produk bawang putih tingkat petani $(\mathrm{Rp} / \mathrm{kg})$ tahun 2011 ; 6) Faktor Internal adalah faktor-faktor kekuatan (Strengths) dan kelemahan (Weaknesses) dari dalam usahatani bawang putih di daerah tersebut, dan; 7) Faktor eksternal adalah faktor-faktor peluang (Opportunities) dan tantangan (threats) yang merupakan faktor yang berasal dari usahatani bawang putih di wilayah tersebut.

Data yang diperoleh dikumpulkan kemudian ditabulasi dan dianalisis berdasarkan tujuan penelitian yaitu 1) Untuk menjawab tujuan pertama, dianalisis dengan pendekatan deskriptif kualitatif, yang dilakukan untuk memperoleh informasi tentang usahatani bawang putih, serta faktor-faktor yang mendukung dan menghambat (peluang dan tantangan) usahatani bawang putih di Kecamatan Miomaffo Barat Kabupaten TTU; 2) Untuk menjawab tujuan kedua, dilakukan perhitungan pendapatan usahatani bawang putih dengan rumus sesuai petunjuk Soekartawi (1995) yaitu : Pd = R - TC Dimana : Pd = Pendapatan TR $=$ Total Penerimaan $\mathrm{TC}=$ Total Biaya; 3) Untuk menjawab tujuan ketiga, dianalisis dengan alat analisis SWOT yaitu suatu analisis mengenai faktor Internal usaha berupa kekuatan (Strengths), kelemahan (Weaknesses), dan faktor eksternal usaha berupa peluang (Opportunities) dan tantangan (Threats). Analisis SWOT dilakukan untuk mengidentifikasi peluang dan tantangan serta merumuskan strategi-strategi dalam menjalankan usahatani bawang putih di Kecamatan Miomaffo Barat Kabupaten TTU. Analisis tersebut dibuat sesuai petunjuk Rangkuti (2003) dengan model matriks seperti pada Tabel 1 .

\begin{tabular}{|c|c|c|}
\hline Faktor internal (IFAS) & Kekuatan (S) & Kelemahan (W) \\
\hline Faktor eksternal (EFAS) & $\begin{array}{l}* \text { Faktor } 1 \\
* \text { Faktor } 2\end{array}$ & $*$ Faktor 1 \\
\hline Peluang $(\mathrm{O})$ & Strategi SO (I) & Strategi WO (III) \\
\hline $\begin{array}{l}* \text { Faktor } 1 \\
* \text { Faktor } 2\end{array}$ & $\begin{array}{l}\text { Strategi menggunakan kekuatan } \\
\text { untuk memanfaatkan peluang }\end{array}$ & $\begin{array}{l}\text { Strategi yang memanfaatkan peluang } \\
\text { untuk mengatasi kelemahan }\end{array}$ \\
\hline Ancaman $(\mathrm{T})$ & Strategi ST (II) & Strategi WT (IV) \\
\hline $\begin{array}{l}\text { * Faktor } 1 \\
\text { * Faktor } 2\end{array}$ & $\begin{array}{l}\text { Strategi menggunakan kekuatan } \\
\text { untuk menghindari ancaman }\end{array}$ & $\begin{array}{l}\text { Strategi yang meminimal kan } \\
\text { kelemahan dan menghindari ancaman }\end{array}$ \\
\hline
\end{tabular}

I. Strategi S-O

Strategi ini dibuat berdasarkan situasi usahatani yang sangat kondusif dengan memanfaatkan seluruh kekuatan untuk merebut dan memanfaatkan peluang sebesar-besarnya. Situasi ini menyarankan strategi yang berorientasi pada pertumbuhan (growth oriented strategy) atau mendukung kebijakan yang agresif. Pertumbuhan yang agresif dapat dilakukan melalui penetrasi pasar, pengembangan pasar dan pengembangan produk.

II. Strategi S-T

Ini adalah strategi dimana perusahaan menggunakan kekuatan tertentu yang dimiliki perusahaan untuk menghadapi lingkungan yang tidak menguntungkan atau ancaman. Kekuatan yang dimiliki akan dimanfaatkan semaksimal mungkin untuk memanfaatkan peluang jangka panjang.

III. Strategi W-O

Strategi ini diterapkan berdasarkan pemanfaatan peluang yang ada dengan cara meminimalkan kelemahan yang ada karena perusahaan menghadapi peluang pasar yang sangat besar tetapi di lain sisi menghadapi kendala kelemahan internal.

IV. Strategi W-T

Strategi ini didasarkan pada kegiatan yang bersifat defensive dan berusaha meminimalkan kelemahan yang ada serta menghindari ancaman karena perusahaan menghadapi situasi yang sangat tidak menguntungkan.

\section{Hasil dan Pembahasan}

3.1 Gambaran Umum Usahatani Bawang Putih

Pengolahan lahan dilakukan oleh tenaga kerja pria maupun wanita yaitu dengan cara tanah dibalik menggunakan linggis kemudian diratakan yang bertujuan untuk memperbaiki struktur tanah menjadi lebih gembur (remah). Disamping itu, sirkulasi udara dalam tanah akan lebih baik, mematikan cendawan dan telur-telur insekta yang terangkat ke permukaan tanah karena panas matahari. Pada kondisi tanah gembur, akan memudahkan perkembangan akar tanaman bawang putih lebih sempurna, sehingga tanaman akan tumbuh subur. Pemakain bibit/benih unggul dapat meningkatkan produksi. Berdasarkan hasil penelitian bibit yang gunakan adalah varietas lokal dari hasil panen sebelumnya. Penanaman biasa dilakukan pada bulan Mei dengan cara sehari sebelum tanam bawang putih yang masih berupa umbi kemudian dikupas, dipipil/dipecah-pecah menjadi beberapa siung kemudian ditanam pada lubang tanam yang dibuat dengan tugal sebanyak 1 siung setiap lubang. Jarak tanam yang dipakai rata-rata $15 \mathrm{~cm}$ x $10 \mathrm{~cm}$. Penyiangan pertama dilakukan pada saat tanaman berumur 2-3 minggu setelah tanam dengan menggunakan alat tofa (tajak), sekaligus bertujuan untuk menggemburkan tanah. Penyiangan berikutnya disesuaikan dengan keadaan pertumbuhan rumput/gulma. Masyarakat jarang bahkan tidak biasa menggunakan pupuk, baik pupuk organik maupun anorganik/kimia. Hal ini disebabkan kurangnya pengetahuan petani manfaat dari penggunaan pupuk bagi tanaman. Petani beranggapan bahwa lahan yang diusahakan masih subur. Pengairan usahatani bawang putih tidak dilakukan secara intensif, karena penanamannya dilakukan diakhir musim hujan sehingga pengairan dilakukan secara alami dengan memanfaatkan sisa curah hujan. Apabila terjadi serangan hama/ penyakit pada tanaman bawang putih, petani kurang tanggap/cepat berupaya untuk mengendalikannya. Hal ini disebabkan beberapa faktor antara lain salah satunya karena petani tidak tahu apa jenis hama/penyakitnya dan bagaimana cara mengendalikannya.

Pemanenan dilakukan setelah mencapai masa umur panen 85-100 hari setelah tanam yang ditandai dengan mengeringnya batang daun. Biasanya petani memanen dengan cara dicabut langsung maupun dicungkil pada tanah yang agak berat, kemudian dikumpulkan sebelum dipisahkan dari batang daunnya setelah terkumpul dibersihkan dengan cara dipotong batang daunnya dan kotoran lainnya. Hasil panen di masukkan kedalam karung plastik kemudian pengangkutan hasil panen dari lokasi ke rumah bisanya dilakukan dengan menggunakan tenaga manusia. Hal ini dikarenakan lokasi panennya tidak jauh dari rumah. Penjemuran dilakukan dengan cara alami memanfaatkan panas sinar matahari langsung yaitu bawang putih hasil panen dihamburkan di atas bentangan alas terpal selama beberapa hari sampai kering. Bawang putih yang sudah kering kemudian dimasukkan ke dalam karung goni/plastik dan disimpan di dalam ruangan rumah atau di atas dapur. Petani biasa menjual hasil produksinya langsung kepada tengkulak. Tengkulak/pedagang datang dilokasi terjadi kesepakatan harga dengan petani maka produk di jual atau dengan cara dijual langsung ke pasar.

\subsection{Produksi, Penerimaan, Biaya Produksi dan Pendapatan}

Sesuai dengan hasil penelitian total produksi bawang putih yang diperoleh adalah sebesar $22.950 \mathrm{~kg}$. Produksi yang diperoleh responden berkisar antara 60- $625 \mathrm{~kg}$ dengan rata-rata per respondennya $260,79 \mathrm{~kg}$. Soekartawi (1995) mendefinisikan penerimaan usahatani adalah perkalian antara produksi dan harga jual. Berdasarkan hasil penelitian total penerimaan yang diperoleh dari seluruh responden sebesar Rp. 344.250.000. Penerimaan yang diperoleh setiap responden berkisar antara Rp. 900.000 - Rp. 11.100.000. Dengan demikian rata-rata penerimaan yang diperoleh sebesar Rp. 3.911.932. Total biaya yang dikeluarkan dari usahatani bawang putih sebesar Rp. 126.635.000. Dengan ratarata biaya yang dikeluarkan setiap responden sebesar Rp. 1.439.034. Pendapatan usahatani merupakan selisih antara penerimaan dengan biaya-biaya yang dikeluarkan untuk proses produksi. Total penerimaan untuk seluruh responden sebesar Rp 344.250.000 dan total biaya sebesar Rp. 126.635.000 Dengan demikian maka total pendapatan yang diperoleh sebesar $\mathrm{Rp}$ 217.615.000. Dengan rata-rata pendapatan sebesar Rp 2.472.898.

\subsection{Analisis SWOT}

Untuk melakukan analisis faktor internal terhadap strategi pengembangan usahatani bawang putih dalam upaya peningkatan pendapatan petani di Kecamatan Miomaffo Barat, terlebih dahulu ditentukan atau diidentifikasi faktor-faktor kekeuatan dan kelemahan sebagai berikut :

1. Kekuatan
a. Kondisi iklim yang mendukung
b. Kondisi tanah subur
c. Petani mengusahakan bawang putih sudah turun-temurun
d. Kondisi kelompok tani dan Gapoktan
e. Akses/ jalan ke pasar
f. Lahan yang masihluas

2. Kelemahan
a. Modal petani kecil
b. Luas garapan yang masih tergolong kecil
c. Produksi tidak kontinyu/terbatas (tergantung musim)
d. Ketersediaan sarana produksi dalam hal bibit, pupuk dan pestisida
e. Kurang Penguasaan teknologi
f. Kualitas SDM petani rendah

Sedangkan faktor eksternal (Peluang dan Ancaman) dapat diidentifikasi sebagai berikut :

1. Peluang
a. Permintaan bawang putih yang kontinu.
b. Harga bawang putih tinggi
c. Tersedia infrastruktur komonikasi \& informasi
d. Kebijakan Pemerintah yang mendukung
e. Terdapat lembaga keuangan baik yang bank maupun non bank 
2. Ancaman

a. Banayak orang yang sudah tertarik dengan usaha bawang putih

b. Terdapat produk sejenis di pasaran (bawang putih dari luar)

c. Harga barang subtitusi yang rendah (harga bawang merah rendah)

d. Iklim yang terkadangtidakmenentu

e. Serangan Hama/Penyakit tanaman bawang putih
SWOT matrik seperti pada Tabel 2. dibangun berdasarkan hasil analisis faktor-faktor strategis baik internal maupun eksternal yang terdiri dari faktor kekuatan, kelemahan, peluang dan ancaman. Dari faktor-faktor internal dan eksternal tersebut, maka digambarkan matrik SWOT, untuk mengetahui bagaimana peluang dan ancaman eksternal yang dihadapi oleh petani di Kecamatan Miomaffo Barat dalam pengembangan usahatani bawang putih dalam upaya peningkatan pendapatan petani, dapat disesuaikan dengan kekuatan dan kelemahan yang dimiliki.

\begin{tabular}{|c|c|c|}
\hline EFAS & \begin{tabular}{ll}
\multicolumn{2}{l}{ STRENGTHS (S) } \\
a. Kondisi iklim yang mendukung \\
b. Kondisi tanah yang subur \\
c. Petani mengusahakan bawang putih sudah turun- \\
d. \\
e. Kondisi kelompok tani \& Gapoktan \\
f. & Lahses/ jalan ke pasar \\
.
\end{tabular} & 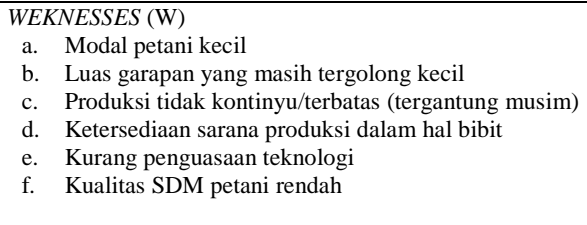 \\
\hline $\begin{array}{l}\text { OPPORTUNIES }(\mathrm{O}) \\
\text { a. Permintaan bawang putih yang kontinu. } \\
\text { b. Harga bawang putih tinggi } \\
\text { c. Tersedia infrastruktur komonikasi \& } \\
\text { informasi } \\
\text { d. Kebijakan pemerintah yang mendukung } \\
\text { e. Terdapat lembaga keuangan baik yang } \\
\text { bank maupun non bank }\end{array}$ & $\begin{array}{l}\text { STRATEGI SO } \\
\text { Strategi: } \\
\text { 1. Meningkatkan produksi bawang putih } \\
\text { Program: } \\
\text { 1. Perluasan areal tanam bawang putih. } \\
\text { 2. Memberdayakan kelompok tani. }\end{array}$ & $\begin{array}{l}\text { STRATEGI WO } \\
\text { Strategi: } \\
\text { - Pemberdayaan petani bawang putih } \\
\text { Program: } \\
\text { 1. Bantuan modal oleh perbankan atau pemda } \\
\text { 2. Peningkatan ketrampilan teknologi maju } \\
\text { 3. Pelatihan petani tentang sistem usahatani bawang putih } \\
\text { 4. kebijakan pemerintah dalam menentukan } \\
\text { harga bawang putih } \\
\text { 5. Meningkatkan produktifitas lahan } \\
\end{array}$ \\
\hline $\begin{array}{l}\text { TREATHS }(\mathrm{T}) \\
\text { a. Banayak orang yang sudah tertarik dengan } \\
\text { usaha bawang putih } \\
\text { b. Terdapat produk sejenis di pasaran } \\
\text { (bawang putih dari luar) } \\
\text { c. Harga barang sustitusi yang rendah (harga } \\
\text { bawang merah rendah) } \\
\text { d. Iklim yang terkadang tidak menentu } \\
\text { e. Serangan hama/penyakit bawang putih }\end{array}$ & 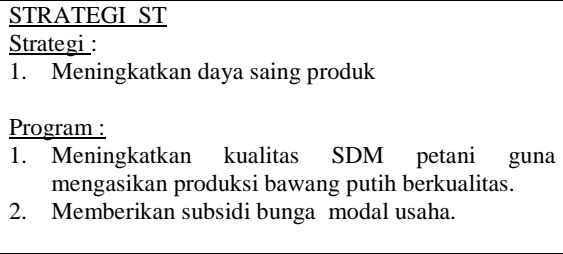 & $\begin{array}{l}\text { STRATEGI WT } \\
\text { Strategi: } \\
\text { - Memperkuat posisi usaha petani } \\
\text { Program: } \\
\text { 1. Pemupukan modal petani } \\
\text { 2. Respon terhadap kemajuan teknologi } \\
\text { 3. Memberikan jaminan pasar. }\end{array}$ \\
\hline
\end{tabular}

\section{Simpulan}

Sistem usahatani bawang putih di Kecamatan Miomaffo Barat belum dikembangkan secara intensif, karena petani belum menerapkan sistem panca usahatani, seperti bibit yang dipakai adalah bibit lokal yang sudah dipakai oleh petani secara turun- temurun, petani tidak menggunakan pupuk baik pupuk organik maupun angornik, sehingga produksi yang dihasilkan juga belum optimal. Pendapatan yang diperoleh oleh petani dalam sekali musim tanam dengan luas garapan rata-rata 15 are sebesar Rp 2.472.898,-.

Hasil analisis SWOT diperoleh koordinat $(-0,08 ; 0,03)$ yang mana koordinat ini pada kuadran III. Posisi ini menandakan sebuah kegiatan usaha yang lemah namun sangat berpeluang. Rekomendasi strategi yang diberikan adalah Ubah Strategi, artinya disarankan untuk mengubah strategi sebelumnya. Sebab, strategi yang lama dikhawatirkan sulit untuk dapat menangkap peluang yang ada sekaligus memperbaiki usahatani yang tepat.

\section{Pustaka}

Badan Pusat Statistik Kabupaten Timor Tengah Utara. 2011. Timor Tengah Utara dalam Angka. Badan Pusat Statistik. Kefamenanu.

Badan Pusat Statistik Provinsi Nusa Tenggara Timur. 2010. Statistik Indonesia. Badan Pusat Statistik. Jakarta.

Rangkuti, F., 2003. Analisis SWOT Teknik Pembedahan Kasus Bisnis. Penerbit PT Gramedia Pustaka Utama. Jakarta.

Samuelson dan Nordhaus. 1993. Perekonomian Indonesia, edisi 2, Jakarta. Erlangga.

Soekartawi. 1995. Ilmu Usahatani dan Penelitian untuk Pengembangan Petani Kecil. UI. Press Jakarta. 